\title{
Maternal and perinatal conditions and the risk of developing celiac disease during childhood
}

\author{
Fredinah Namatovu ${ }^{1 *}$, Cecilia Olsson², Marie Lindkvist ${ }^{1}$, Anna Myléus ${ }^{1}$, Ulf Högberg ${ }^{1,3}$, Anneli Ivarsson ${ }^{1}$ \\ and Olof Sandström ${ }^{4}$
}

\begin{abstract}
Background: Celiac disease (CD) is increasing worldwide, which might be due to the changing environmental and lifestyle exposures. We aimed to explore how conditions related to maternity, delivery and the neonatal period influence CD onset during childhood.

Methods: Using Sweden's national registers we had access to information on 1912204 children born between 1991 and 2009, 6596 of whom developed CD before 15 years of age. Logistic regression analyses were performed to determine how CD is associated with maternity, delivery and the neonatal period.

Results: Regardless of sex, a reduction in CD risk was observed in children born to mothers aged $\geq 35$ years (odds ratio [OR] 0.8; 95 \% confidence interval [CI] 0.7-0.9) and with high maternal income (OR 0.9; $95 \%$ Cl 0.8-0.9). Being a second-born child, however, was positively associated with CD. Among boys, elective caesarean delivery increased the risk of $\mathrm{CD}(\mathrm{OR} 1.2 ; 95 \% \mathrm{Cl} 1.0-1.4)$, while maternal overweight (OR 0.9; $95 \% \mathrm{Cl}$ 0.8-0.9), premature rupture of the membrane (OR 0.4; $95 \% \mathrm{Cl} 0.2-0.8$ ) and low birth weight showed a negative association. Girls had an increased CD risk compared to boys and in girls the risk was increased by repeated maternal urinary tract infections (OR 1.1; $95 \%$ Cl 1.0-1.2).
\end{abstract}

Conclusions: Elective caesarean delivery and repeated maternal urinary tract infections during pregnancy are associated with increased risk of CD onset during childhood, suggesting the role of dysbiosis during early life. High maternal age and high income reduced the risk of $C D$, which might be due to infant-feeding practices and life style.

Keywords: Celiac disease, Caesarean, Children, Delivery, Elective, Income, Infections, Perinatal, Pregnancy, Register

\section{Background}

Celiac disease $(\mathrm{CD})$ is an immune mediated enteropathy triggered by exposure to dietary gluten in genetically susceptible individuals [1]. Epidemiological studies suggest the role of environmental risk factors as exemplified by the worldwide recognition of $\mathrm{CD}$, geographical variation in incidence and increase in $\mathrm{CD}$ frequency that cannot be fully explained by increased awareness among doctors and the public [2-6]. Sweden recorded pronounced differences in CD incidence between birth cohorts, best represented by the Swedish CD epidemic 1985-1996, but

\footnotetext{
* Correspondence: fredinah.namatovu@epiph.umu.se

'Department of Public Health and Clinical Medicine, Epidemiology and

Global Health, Umeå University, SE-901 87 Umeå, Sweden

Full list of author information is available at the end of the article
}

also by more recent variations [2]. Kondroshova et al. found a five-fold difference in CD prevalence between Finland and adjacent Karelia [7]. CD is almost twice as common in southern Sweden compared to the central and northern parts without any known genetic differences in the population [8]. However, the environmental factors that are of importance in explaining these differences are not yet fully established.

The immune system develops through interaction with the environmental factors and it is assumed that early life events, including fetal life, play a major role in this process. This includes interactions between the mother and the fetal immune system with tolerogenic processes that begin during fetal life [9]. Maternal health, including obesity, has been shown to influence immune development 
[10]. A well-functioning immune system is also dependent on a healthy gut microbiota. Colonization of the gut begins at delivery with the transferral of microflora from the maternal birth canal, faeces and skin. The neonates' microbiota are thus affected by mode of delivery but also by factors affecting the maternal microbiota before delivery [11]. Changes in the infant's microbiota have been shown to occur following birth, infections, antibiotic use and diet (in particular breastfeeding), thus influencing the immune system [12-14]. Given this background, factors related to maternal health and other early life events that impact these processes are of interest to study in relation to CD risk. Several previous studies have suggested that early life events related to maternity, pregnancy, delivery and neonatal life influence the risk of developing CD [15-18]. In the present study, we use a large database consisting of the entire Swedish child population and subsequent childhood CD cases identified nationwide with the aim of investigating how conditions related to maternity, delivery and the neonatal period influence the risk of getting a CD diagnosis during childhood.

\section{Methods}

The study population consisted of 1912204 live births. The Umeå SIMSAM Lab (SIMSAM: Swedish Initiative for Research on Microdata in the Medical and Social Sciences) was used to access linked data on all children born in Sweden from 1991 to 2009 and their respective mothers. Data on the total population and perinatal events were obtained from the Medical Birth Register, income data were obtained from the Longitudinal Integration Database for Health Insurance and Labour Market Studies, and data on CD from the Swedish National Childhood CD Incidence Register [4]. Data linkage was performed by Statistics Sweden using the children's Swedish personal identity number (PIN) [19].

\section{Celiac disease case ascertainment}

CD ascertainment was based on the European Society for Paediatric Gastroenterology, Hepatology and Nutrition's (ESPGHAN) diagnostic criteria from 1990 requiring villous atrophy on a normal diet followed by clinical remission on a gluten-free diet [20]. Small intestinal biopsies were first assessed according to the Alexander classification and thereafter by the Marsh-Oberhuber classification [21]. Other details concerning the register have been published earlier [4]. The study included 6 596 children who fulfilled the CD diagnostic criteria and were reported with a PIN necessary for data linkage.

\section{Exclusion criteria}

Before data linkage, Statistics Sweden excluded all abortions, stillbirths, early neonatal deaths ( $\leq 30$ days of birth) and new-borns whose birth weight was recorded as $<1000 \mathrm{~g}$.
Also 1498 (18.5\%) children were excluded because they were reported to the Swedish National Childhood CD Incidence Register without a PIN. To avoid misclassification of CD cases, we only included cases where villous atrophy had been confirmed according to ESPGHAN's guidelines, see the previous section. We thus excluded cases without villous atrophy even if they had elevated serological markers and cases with minor enteropathy even if they had symptoms suggesting CD.

\section{Assessment of the maternity, pregnancy, delivery and neonatal life characteristics}

We included 15 characteristics because either previous research suggested them as plausible in CD etiology and/or because of their potential relationship with the immune system development during childhood. Factors with possible effects on maternal health and life style included maternal age at delivery. This was categorized into four groups: $<25,25-29,30-34$ and $\geq 35$ years (no information available for $0.1 \%$ ). Maternal disposable income during pregnancy with the index child (per 100 SEK) was categorized into three predefined strata based on quartile ranges (no information available for $1.3 \%$ children). Maternal smoking during pregnancy was categorized into no smoking, smoking 1-9 cigarettes per day and smoking $\geq 10$ cigarettes per day. Because of the absence of a linear relationship, we re-categorized this into yes if a mother smoked and no if no smoking was reported (Information was missing in $5.5 \%$ children). Maternal body mass index (BMI) measured at first antenatal visit was divided into underweight $(<18.5)$, normal weight (18.5-24.9), overweight (25.0-29.9) and obesity ( $\geq 30.0)$, (information was missing in $19.9 \%$ ).

As marker for exposure to infections the following variables were included; parity, maternal and neonatal infections. Parity was included as a measure of number of sibling, because number of siblings is associated with frequency of infections [22]. A child was defined as parity 1 if the mother had never given birth previously, parity 2 if the current child was the second child and parity $\geq 3$ represented child number three and above (information was missing in $0.001 \%$ ). Maternal infections during pregnancy and neonatal infections were included because they are associated with increased stress to the foetus. Additionally, children with infections are often treated with antibiotics that have an effect on the microbiota. These were classified according to the WHO International Classification of Diseases (ICD) 9th and/or 10th revisions (Table 1). Children were coded yes if the condition was reported and the rest were coded no. No missing information was reported.

Additional markers of health and stress of the foetus/ child were as follows; duration of pregnancy, which was categorized as either born at gestational age $<37$ weeks 
Table 1 ICD codes used to identify diagnoses in this study

\begin{tabular}{lll}
\hline Description & ICD 10 & ICD 9 \\
\hline $\begin{array}{l}\text { Maternal infections } \\
\text { Infections of genitourinary tract }\end{array}$ & O23 & $\begin{array}{l}646.60,646.61, \\
646.62,646.63\end{array}$ \\
$\begin{array}{l}\text { in pregnancy } \\
\text { Infections of amniotic sac and }\end{array}$ & O41.1 & $658.41,658.43$ \\
$\begin{array}{l}\text { membranes } \\
\text { Pyrexia during labour, not elsewhere } \\
\text { classified }\end{array}$ & O75.2 & 659.21 \\
$\begin{array}{l}\text { Other infection during labour } \\
\text { Premature rupture of the membrane }\end{array}$ & O75.3 & 659.31 \\
$\begin{array}{l}\text { Premature rupture of the membrane, } \\
\text { onset of labour }\end{array}$ & O42 & \\
$\begin{array}{l}\text { Neonatal infections } \\
\text { Pneumonia }\end{array}$ & & \\
Sepsis & P23 & 770.0 \\
Other neonatal infections & P36 & 771.81 \\
& P39 & $771.5,771.6$, \\
\hline
\end{tabular}

ICD International Classification of Diseases

The Swedish ICD system used was constructed based on the ICD classification of the World Health Organization

or $\geq 37$ weeks, (information was missing in $0.1 \%$ children) [23]. Infant birth weight in grams was categorized into very low birth weight $(<1500 \mathrm{~g})$, low birth weight (1500-2499 g) and normal birth weight ( $\geq 2500 \mathrm{~g}$ ) (information on birth weight was missing in $0.3 \%)$. Sex was either male or female and no data was missing. Small for gestational age was categorized into yes and no and data was missing in $3.3 \%$ of children. Apgar score at five minutes after birth was recorded on a scale of 0-10: it was categorized into low Apgar score $(<7)$ and normal Apgar score $(\geq 7)$ (information was missing in $0.3 \%$ children).

To study possible effects of delivery on gut microbiota, mode of delivery was categorized into caesarean and vaginal, caesarean delivery was further divided into elective and emergency. Premature rupture of the membrane (PROM) was classified according ICD 9th and/or 10th revisions.

\section{Statistical analysis}

All statistical analyses were performed using SPSS 22 for Windows. For descriptive analysis, two-by-two tables were used to compare CD cases with non-cases. Bivariate analyses using logistic regression were performed to determine the independent associations between CD and the studied explanatory variables.

Multivariate logistic regression analyses were performed in order to adjust for multiple explanatory variables and thereby reduce any potential bias resulting from differences in the compared groups. The multivariate logistic regression models only included variables that were statistically significant in their preceding bivariate models. For categorical variables, all categories were retained as long as there was a category that was statistically significant in the bivariate analysis. All analyses were repeated separately for boys and girls, except in the post hoc analysis. Odds ratios (ORs) with $95 \%$ confidence intervals (CIs) were calculated to estimate the risk of acquiring CD in the context of various conditions. Statistical significance was attained with a $p<0.05$, Missing data was excluded only for terms included in the analyses.

\section{Post hoc analyses}

To determine if the nature of maternal infections during pregnancy influenced CD risk differently, we categorized infections into urinary tract infections and other infections and examined the risk of CD depending on these categories. We also hypothesized that CD risk may differ based on a combined effect of maternal age, income and urinary tract infections. Two groups were formed: mothers aged $>35$ years with high income and no urinary tract infections and these were compared with mothers aged $<35$ years, with middle/low income and with urinary tract infections.

\section{Results \\ Background information}

CD was almost twice as common in girls compared to boys. The highest proportion of mothers with children diagnosed with CD were aged 25-29 years and belonged to the middle-income quartile. In the study population, $15 \%$ of the children were delivered by caesarean section. All basic characteristics of this population are shown in Table 2.

\section{Bivariate and multivariate results for all children}

In the bivariate analysis, increased childhood CD risk was significantly associated with maternal age 25-29 years (compared to $<25$ years), middle income (compared to low), being a second born child (compared to being the first), maternal infections in general during pregnancy (compared to no infections during pregnancy), and being a female (Table 3 ). Reduced CD risk was independently associated with maternal age $\geq 35$ years (compared to $<25$ years), high maternal income (compared to low), maternal overweight (compared to normal weight), parity $\geq 3$ (compared to being a first child), preterm delivery (compared to full term), PROM (compared to not PROM), very low birth weight (compared to normal), and low Apgar score at $5 \mathrm{~min}$ after delivery (compared to high). No independent association was found between $\mathrm{CD}$ and maternal smoking, maternal underweight or obesity, mode of delivery, low birth weight, being small for gestation age, neonatal infections and other maternal infections. 
Table 2 Maternal and perinatal characteristics for children, with and without celiac disease (CD) born in Sweden during 1991-2009

\begin{tabular}{|c|c|c|c|}
\hline Descriptives & & $\begin{array}{l}\text { CD Cases } \\
N(\%) \\
(\text { Total }=6596)\end{array}$ & $\begin{array}{l}\text { Not CD cases } \\
\text { N (\%) } \\
\text { (Total = } 1912 \text { 204) }\end{array}$ \\
\hline \multirow[t]{4}{*}{ Maternal age (years) } & $<25$ & $1155(17.5)$ & $329634(17.3)$ \\
\hline & $25-29$ & $2527(38.3)$ & $639023(33.6)$ \\
\hline & $30-34$ & $2077(31.5)$ & $612299(32.2)$ \\
\hline & $\geq 35$ & $837(12.7)$ & $322300(16.9)$ \\
\hline \multirow[t]{3}{*}{ Disposable income (Per 100 SEK) } & Low & $2224(33.8)$ & $627366(33.4)$ \\
\hline & Middle & $2558(38.9)$ & $625586(33.4)$ \\
\hline & High & $1799(27.3)$ & $627253(33.4)$ \\
\hline \multirow[t]{2}{*}{ Smoking during pregnancy } & No & $5423(86.4)$ & 1560509 (86.6) \\
\hline & Yes & $853(13.6)$ & $240677(13.4)$ \\
\hline \multirow[t]{4}{*}{ Body mass index $\left(\mathrm{kg} / \mathrm{m}^{2}\right)$} & $<18.5$ & $148(2.8)$ & $40844(2.7)$ \\
\hline & $18.5-24.9$ & $3494(65.8)$ & $977145(64.1)$ \\
\hline & $25.0-29.9$ & $1190(22.4)$ & $358566(23.5)$ \\
\hline & $>30$ & $481(9.1)$ & $147426(9.7)$ \\
\hline \multirow[t]{3}{*}{ Parity (n) } & 1 & $2692(40.8)$ & $806990(42.3)$ \\
\hline & 2 & $2657(40.3)$ & $695173(36.5)$ \\
\hline & $\geq 3$ & $1247(18.9)$ & $403408(21.2)$ \\
\hline \multirow[t]{2}{*}{ Duration of pregnancy (weeks) } & $37-45$ & $6256(94.9)$ & $1788057(93.9)$ \\
\hline & $<37$ & $335(5.1)$ & $115524(6.1)$ \\
\hline \multirow[t]{2}{*}{ Premature rupture of the membrane } & No & $6546(99.2)$ & 1883116 (98.8) \\
\hline & Yes & $50(0.8)$ & $22482(1.2)$ \\
\hline \multirow[t]{2}{*}{ Mode of delivery } & Vaginal & $5659(85.8)$ & $1602943(84.9)$ \\
\hline & Caesarean & $937(14.2)$ & $284634(15.1)$ \\
\hline \multirow[t]{2}{*}{ Caesarean delivery } & Elective & $434(46.3)$ & $134351(47.2)$ \\
\hline & Emergency & $503(53.7)$ & $150283(52.8)$ \\
\hline \multirow[t]{3}{*}{ Infant birth weight (grams) } & $<1500$ & $30(0.5)$ & $14049(0.7)$ \\
\hline & $1500-2499$ & $212(3.2)$ & $67129(3.5)$ \\
\hline & $\geq 2500$ & $6336(96.3)$ & $1818885(95.4)$ \\
\hline \multirow[t]{2}{*}{ Sex } & Male & $2412(36.6)$ & $980289(51.4)$ \\
\hline & Female & $4184(63.4)$ & $925309(48.6)$ \\
\hline \multirow[t]{2}{*}{ Small for gestational age } & No & $6225(97.8)$ & $1800454(97.7)$ \\
\hline & Yes & $140(2.2)$ & $43148(2.3)$ \\
\hline \multirow[t]{2}{*}{ Apgar score at $5 \mathrm{~min}$} & $\geq 7$ & $6513(99.4)$ & $1869284(98.9)$ \\
\hline & $<7$ & $42(0.6)$ & $20894(1.1)$ \\
\hline \multirow[t]{2}{*}{ Neonatal infections } & No & $6521(98.9)$ & $1885798(98.9)$ \\
\hline & Yes & $75(1.14)$ & $19800(1.0)$ \\
\hline \multirow[t]{2}{*}{ Maternal infections ${ }^{a}$} & No & $5670(86.0)$ & $1657790(87.0)$ \\
\hline & Yes & $926(14.0)$ & $247808(13.0)$ \\
\hline
\end{tabular}

SEK Swedish Krona

${ }^{a}$ Maternal infections; urinary tract infection and other maternal infections

In the multivariate analyses, increased $\mathrm{CD}$ risk remained statistically associated with maternal age 25-29 years, middle disposable income, being a second born child, being female, and with maternal infections (Table 3). A reduction in $\mathrm{CD}$ risk remained associated with maternal age $\geq 35$ years, high disposable income, maternal 
Table 3 Celiac disease risk in relation to each specific maternal and perinatal condition for all children and divided for boys and girls, respectively (Results from the bivariate analysis)

\begin{tabular}{|c|c|c|c|c|c|c|c|}
\hline \multirow[t]{2}{*}{ Maternal and perinatal exposures } & & \multicolumn{2}{|l|}{ All children } & \multicolumn{2}{|l|}{ Boys } & \multicolumn{2}{|l|}{ Girls } \\
\hline & & OR $(95 \% \mathrm{Cl})$ & $P$-value & OR $(95 \% \mathrm{Cl})$ & $P$-value & OR $(95 \% \mathrm{Cl})$ & $P$-value \\
\hline \multirow[t]{4}{*}{ Maternal age (years) } & $<25$ & 1.0 & & 1.0 & & 1.0 & \\
\hline & $25-29$ & $1.1(1.1-1.2)$ & 0.01 & $1.1(0.9-1.3)$ & 0.06 & $1.1(1.1-1.2)$ & 0.005 \\
\hline & $30-34$ & $0.9(0.9-1.0)$ & 0.4 & $0.9(0.9-1.1)$ & 0.68 & $1.9(1.9-1.1)$ & 0.4 \\
\hline & $\geq 35$ & $0.7(0.7-0.8)$ & $<0.001$ & $0.7(0.6-0.9)$ & $<0.001$ & $0.8(0.7-0.8)$ & $<0.001$ \\
\hline \multirow{3}{*}{$\begin{array}{l}\text { Disposable income } \\
\text { (per } 100 \text { SEK) }\end{array}$} & Low & 1.0 & & 1.0 & & 1.0 & \\
\hline & Middle & $1.2(1.1-1.2)$ & $<0.001$ & $1.1(1.0-1.3)$ & 0.07 & $1.2(1.1-1.2)$ & $<0.001$ \\
\hline & High & $0.8(0.8-0.9)$ & $<0.001$ & $0.8(0.7-0.9)$ & $<0.001$ & $0.8(0.8-0.9)$ & $<0.001$ \\
\hline \multirow[t]{2}{*}{ Smoking during pregnancy } & No & 1.0 & & 1.0 & & 1.0 & \\
\hline & Yes & $1.0(0.9-1.1)$ & 0.59 & $0.9(0.9-1.1)$ & 0.57 & $1.1(0.9-1.2)$ & 0.25 \\
\hline \multirow[t]{4}{*}{ Body mass index $\left(\mathrm{kg} / \mathrm{m}^{2}\right)$} & $18.50-24.99$ & 1.0 & & 1.0 & & 1.0 & \\
\hline & $<18.50$ & $1.0(0.9-1.2)$ & 0.87 & $0.9(0.8-1.3)$ & 0.95 & $1.0(0.8-1.3)$ & 0.86 \\
\hline & $25.00-29.99$ & $0.9(0.9-0.9)$ & 0.03 & $0.9(0.8-0.9)$ & 0.03 & $0.9(0.9-1.0)$ & 0.27 \\
\hline & $\geq 30$ & $0.9(0.8-1.0)$ & 0.06 & $0.9(0.7-1.0)$ & 0.05 & $0.9(0.8-1.1)$ & 0.40 \\
\hline \multirow[t]{3}{*}{ Parity (n) } & 1 & 1.0 & & 1.0 & & 1.0 & \\
\hline & 2 & $1.1(1.1-1.2)$ & $<0.001$ & $1.1(1.1-1.2)$ & 0.01 & $1.2(1.1-1.2)$ & $<0.001$ \\
\hline & $\geq 3$ & $0.9(0.9-0.9)$ & 0.03 & $0.9(0.9-1.1)$ & 0.51 & $0.9(0.8-0.9)$ & 0.02 \\
\hline \multirow[t]{2}{*}{ Duration of pregnancy (weeks) } & $37-45$ & 1.0 & & 1.0 & & 1.0 & \\
\hline & $<37$ & $0.8(0.7-0.9)$ & 0.001 & $0.8(0.7-0.9)$ & 0.04 & $0.9(0.7-0.9)$ & 0.02 \\
\hline \multirow[t]{2}{*}{ Premature rupture of the membrane } & No & 1.00 & & 1.0 & & 1.00 & \\
\hline & Yes & $0.6(0.5-0.9)$ & 0.002 & $0.4(0.2-0.7)$ & 0.001 & $0.8(0.6-1.2)$ & 0.28 \\
\hline \multirow[t]{2}{*}{ Mode of delivery } & Vaginal & 1.0 & & 1.0 & & 1.0 & \\
\hline & Caesarean & $0.9(0.9-1.0)$ & 0.09 & $0.9(0.9-1.1)$ & 0.49 & $0.9(0.9-1.1)$ & 0.25 \\
\hline \multirow[t]{3}{*}{ Caesarean delivery } & Vaginal & 1.0 & & 1.0 & & 1.0 & \\
\hline & Elective & $0.9(0.8-1.0)$ & 0.14 & $0.8(0.7-1.0)$ & 0.03 & $0.9(0.9-1.1)$ & 0.73 \\
\hline & Emergency & $0.9(0.9-1.1)$ & 0.43 & $1.1(0.9-1.2)$ & 0.29 & $0.9(0.8-1.1)$ & 0.23 \\
\hline \multirow[t]{3}{*}{ Infant birth weight (grams) } & $\geq 2500$ & 1.0 & & 1.0 & & 1.0 & \\
\hline & $1500-2499$ & $0.9(0.8-1.0)$ & 0.16 & $0.9(0.7-1.1)$ & 0.38 & $0.9(0.8-1.0)$ & 0.15 \\
\hline & $<1500$ & $0.6(0.4-0.9)$ & 0.01 & $0.4(0.2-0.8)$ & 0.01 & $0.7(0.5-1.1)$ & 0.15 \\
\hline \multirow[t]{2}{*}{ Sex } & Male & 1.0 & & & & & \\
\hline & Female & $1.8(1.8-1.9)$ & $<0.001$ & & & & \\
\hline \multirow[t]{2}{*}{ Small for gestational age } & No & 1.0 & & 1.0 & & 1.0 & \\
\hline & Yes & $0.9(0.8-1.1)$ & 0.46 & $0.9(0.7-1.3)$ & 0.69 & $0.9(0.8-1.2)$ & 0.49 \\
\hline \multirow[t]{2}{*}{ Apgar score at $5 \mathrm{~min}$} & $\geq 7$ & 1.0 & & 1.0 & & 1.0 & \\
\hline & $<7$ & $0.6(0.4-0.8)$ & $<0.001$ & $0.8(0.5-1.1)$ & 0.18 & $0.5(0.3-0.8)$ & 0.001 \\
\hline \multirow[t]{2}{*}{ Maternal infections ${ }^{a}$} & No & 1.0 & & 1.0 & & 1.0 & \\
\hline & Yes & $1.1(1.0-1.2)$ & 0.01 & $1.0(0.9-1.2)$ & 0.67 & $1.1(1.0-1.2)$ & 0.005 \\
\hline \multirow[t]{2}{*}{ Neonatal infections } & No & 1.0 & & 1.0 & & 1.0 & \\
\hline & Yes & $1.1(0.9-1.2)$ & 0.43 & $1.2(0.9-1.7)$ & 0.24 & $1.1(0.8-1.5)$ & 0.50 \\
\hline
\end{tabular}

OR odds ratio, $\mathrm{Cl}$ confidence interval, SEK Swedish Krona: Bivariate logistic regression analyses were performed for all variables, and results reported regardless of statistical significance 
overweight, PROM, and low Apgar score. CD was not associated with maternal underweight or obesity, parity $\geq 3$, preterm birth and birth weight (Table 3).

\section{Sex specific bivariate and multivariate analyses}

We found several factors that only had a relation to CD in one of the sexes. Among boys, elective caesarean delivery was associated with increased $C D$ risk in the multivariate model despite an independent reduced $C D$ risk (Table 4). In both the bivariate and the multivariate model, maternal overweight, PROM and very low birth weight were associated with reduced $\mathrm{CD}$ risk. Although low birth weight was associated with reduced $\mathrm{CD}$ risk in the bivariate model, this association was not statistically significant after adjustment. Specifically for girls, the bivariate and multivariate analyses showed increased $C D$ risk to be associated with maternal infections while low Apgar score was associated with reduced CD risk. The effect of other factors remained similar in boys and girls except for marginal differences in the ORs.

\section{Post hoc analyses}

Both bivariate and multivariate results showed increased $\mathrm{CD}$ risk to be associated with maternal urinary tract infections, while other maternal infections showed no association (Table 5). In further stratification, CD risk

Table 4 Celiac disease risk in relation to each specific maternal and perinatal condition for all children and divided for boys and girls, respectively (Results from the multivariate analysis)

\begin{tabular}{|c|c|c|c|c|c|c|c|}
\hline \multirow[t]{2}{*}{ Maternal and perinatal exposures } & & \multirow{2}{*}{$\begin{array}{l}\text { All children } \\
\text { OR (95 \% Cl) }\end{array}$} & \multirow[b]{2}{*}{$P$-value } & \multicolumn{2}{|l|}{ Boys } & \multicolumn{2}{|l|}{ Girls } \\
\hline & & & & OR $(95 \% \mathrm{Cl})$ & $P$-value & OR $(95 \% \mathrm{Cl})$ & $P$-value \\
\hline \multirow[t]{4}{*}{ Maternal age } & $<25$ & 1.0 & & 1.0 & & 1.0 & \\
\hline & $25-29$ & $1.1(1.0-1.2)$ & 0.01 & $1.1(1.0-1.3)$ & 0.07 & $1.1(1.0-1.2)$ & 0.04 \\
\hline & $30-34$ & $1.0(0.9-1.1)$ & 0.75 & $1.0(0.9-1.2)$ & 0.87 & $1.0(0.9-1.1)$ & 0.52 \\
\hline & $\geq 35$ & $0.8(0.7-0.9)$ & $<0.001$ & $0.8(0.7-0.9)$ & 0.01 & $0.8(0.7-0.9)$ & $<0.001$ \\
\hline \multirow{3}{*}{$\begin{array}{l}\text { Disposable income } \\
\text { (per } 100 \text { SEK) }\end{array}$} & Low & 1.0 & & 1.0 & & 1.0 & \\
\hline & Middle & $1.2(1.1-1.2)$ & $<0.001$ & $1.1(1.0-1.3)$ & 0.01 & $1.2(1.1-1.3)$ & $<0.001$ \\
\hline & High & $0.9(0.8-0.9)$ & $<0.001$ & $0.8(0.7-0.9)$ & 0.01 & $0.9(0.8-0.9)$ & 0.002 \\
\hline \multirow[t]{4}{*}{ Body mass index $\left(\mathrm{kg} / \mathrm{m}^{2}\right)$} & $18.50-24.99$ & 1.0 & & 1.00 & & & \\
\hline & $<18.50$ & $1.0(0.8-1.2)$ & 0.85 & $1.0(0.7-1.3)$ & 0.90 & & \\
\hline & $25.00-29.99$ & $0.9(0.9-0.9)$ & 0.04 & $0.9(0.8-0.9)$ & 0.03 & & \\
\hline & $\geq 30$ & $0.9(0.8-1.0)$ & 0.09 & $0.8(0.7-0.9)$ & 0.04 & & \\
\hline \multirow[t]{3}{*}{ Parity (n) } & 1 & 1.0 & & 1.00 & & 1.00 & \\
\hline & 2 & $1.2(1.1-1.2)$ & $<0.001$ & $1.2(1.0-1.3)$ & 0.01 & $1.2(1.1-1.2)$ & $<0.001$ \\
\hline & $\geq 3$ & $1.0(0.9-1.1)$ & 0.58 & $1.1(0.9-1.2)$ & 0.34 & $1.0(0.9-1.1)$ & 0.53 \\
\hline \multirow{2}{*}{$\begin{array}{l}\text { Duration of pregnancy } \\
\text { (weeks) }\end{array}$} & $37-45$ & 1.0 & & 1.00 & & 1.00 & \\
\hline & $<37$ & $0.9(0.8-1.2)$ & 0.86 & $1.1(0.8-1.4)$ & 0.62 & $0.9(0.8-1.0)$ & 0.90 \\
\hline \multirow[t]{2}{*}{ Premature rupture of the membrane } & No & 1.00 & & 1.00 & & & \\
\hline & Yes & $0.7(0.5-0.9)$ & 0.02 & $0.4(0.2-0.8)$ & 0.01 & & \\
\hline \multirow[t]{2}{*}{ Mode of delivery } & Vaginal & & & 1.00 & & & \\
\hline & Elective & & & $1.2(1.0-1.4)$ & 0.02 & & \\
\hline \multirow[t]{3}{*}{ Infant birth weight (grams) } & $\geq 2500$ & 1.0 & & 1.00 & & & \\
\hline & $1500-2499$ & $1.0(0.9-1.2)$ & 0.73 & $1.0(0.7-1.3)$ & 0.97 & & \\
\hline & $<1500$ & $0.8(0.5-1.2)$ & 0.27 & $0.3(0.1-0.9)$ & 0.03 & & \\
\hline \multirow[t]{2}{*}{ Sex } & Male & 1.0 & & & & & \\
\hline & Female & $1.8(1.7-1.9)$ & $<0.001$ & & & & \\
\hline \multirow{2}{*}{$\begin{array}{l}\text { Apgar score } \\
\text { at } 5 \mathrm{~min}\end{array}$} & $\geq 7$ & 1.0 & & & & 1.00 & \\
\hline & $<7$ & $0.7(0.5-0.9)$ & 0.02 & & & $0.5(0.3-0.8)$ & 0.003 \\
\hline \multirow[t]{2}{*}{ Maternal infections ${ }^{a}$} & No & 1.0 & & & & 1.00 & \\
\hline & Yes & $1.1(1.1-1.2)$ & $<0.001$ & & & $1.1(1.0-1.2)$ & 0.006 \\
\hline
\end{tabular}

OR odds ratio, $\mathrm{Cl}$ confidence interval, SEK Swedish Krona

Multivariate logistic regression including all variables found to be statistically significant $(p<0.05)$ in the bivariate analyses (Table 3$)$

${ }^{a}$ Includes both urinary tract infections and other maternal infections 
Table 5 Celiac disease risk in relation to maternal infections during early life in all children

\begin{tabular}{|c|c|c|c|c|c|c|}
\hline \multirow{3}{*}{ Exposures } & \multicolumn{2}{|l|}{ Descriptive } & & & & \\
\hline & \multirow{2}{*}{$\begin{array}{l}\text { CD Cases } \\
N(\%)\end{array}$} & \multirow{2}{*}{$\begin{array}{l}\text { Not CD cases } \\
N(\%)\end{array}$} & \multicolumn{2}{|c|}{ Bivariate analyses } & \multicolumn{2}{|c|}{ Multivariable analyses } \\
\hline & & & OR $(95 \% \mathrm{Cl})$ & $P$-value & OR $(95 \% \mathrm{Cl})$ & $P$-value \\
\hline \multicolumn{7}{|c|}{ Urinary tract infections } \\
\hline No & $5700(86)$ & $1667663(88)$ & 1.0 & & 1.0 & \\
\hline Yes & $896(14)$ & $237935(13)$ & $1.1(1.0-1.2)$ & 0.007 & $1.2(1.1-1.2)^{a}$ & $<0.001$ \\
\hline \multicolumn{7}{|c|}{ Other maternal infections } \\
\hline No & $6561(99)$ & $1893642(99)$ & 1.0 & & 1.0 & \\
\hline Yes & $35(0.5)$ & $11956(0.6)$ & $0.8(0.6-1.2)$ & 0.32 & $0.9(0.7-1.4)^{\mathrm{a}}$ & 0.80 \\
\hline \multicolumn{7}{|c|}{ urinary tract infections, $<35$ years, Low income } \\
\hline Yes & $689(63)$ & 136479 (48) & 1.0 & & 1.0 & \\
\hline No & $343(37)$ & $150895(53)$ & $0.5(0.5-0.6)$ & $<0.001$ & $0.5(0.4-0.6)^{b}$ & $<0.001$ \\
\hline
\end{tabular}

was significantly reduced in children with mothers who had no urinary tract infections, were aged $\geq 35$ years and had high income.

\section{Discussion}

Our results showed that the risk of developing CD during childhood was associated with several environmental exposures during pregnancy and neonatal period. A reduced risk was associated with high maternal age and high maternal disposable income, while being a second born child was associated with increased risk. Specifically for boys, increased $\mathrm{CD}$ risk was associated with elective caesarean delivery, but negatively associated with maternal overweight, premature rupture of the membrane and low birth weight. Among girls, CD risk was positively associated with maternal infections, but negatively associated with low Apgar score at $5 \mathrm{~min}$. We also found that combining several factors that seemed to have a strong effect (high maternal age, high income and no repeated urinary tract infections had a synergistic effect of reducing $C D$ risk.

One of the strength of this study is that it was based on the entire child population in Sweden born during between 1991 and 2009 and 6500 biopsy-verified CD cases, which provided enough statistical power to guarantee high precision in our estimates and enabled adjustment for several variables. The high number of $\mathrm{CD}$ cases also enabled sub-analyses by age group, comparing children diagnosed at age $<2$ years and 214.9 years, respectively, although no major differences were found (data not shown).

Another strength, our $\mathrm{CD}$ cases were identified through the Swedish National Childhood CD Incidence Register reported from all paediatric departments across the country [4]. We used strict diagnostic criteria to avoid misclassification. It is important to note that during this study period there were no changes in the national recommendations on paediatric $\mathrm{CD}$ diagnosis, moreover the revised ESPGHAN guidelines were introduced later, in 2012 [24].

One of the limitations of this study was that some potentially interesting information was missing, which is a consequence of relying on data from registers. As shown, the proportion of individuals with missing information on the studied exposures was $\sim 0-20 \%$. However, this did not differ between $\mathrm{CD}$ cases and non-cases. Moreover, data on risk factors was prospectively collected and this was done separately prior to linkage with CD data. This is an advantage since it eliminates the problem of recall bias that often affects retrospective studies. Another limitation is that $\mathrm{CD}$ cases without a PIN code were excluded. The main reason why some lacked a PIN code was because some parents were not asked for informed consent, while a few declined to participate. It can be speculated that parents with lower income more often than others declined to participate; however, this is unlikely and it could not have influenced our results in any major way.

In this study the association between maternal age and $\mathrm{CD}$ risk indicated no progression in risk and it is not obvious why different maternal ages would influence $C D$ risk differently. We hypothesize that maternal age at delivery might be a marker for lifestyle aspects for example older mothers are more likely to practise prolonged and exclusive breastfeeding [25-27]. The gut microbiota of breastfed infants differ in composition compared to formula fed infants [11]. Moreover, human milk contains immunoactive substances and present food antigens in small proportions that might have a positive effect on the tolerogenic process [14]. Earlier studies suggested a protective effect of breastfeeding against $\mathrm{CD}$ and are 
summarized in a meta-analysis published by Akobeng and Thomas [28]. However, more recent studies could not confirm this association [29-32]. Worth noting is that all studies on breastfeeding and CD are observational in nature. Performing randomized studies is impossible for ethical reasons since breastfeeding is considered superior to formula feeding. Unfortunately, we lacked data on breastfeeding and could not show a direct association. We also considered parity and disposable income in the adjusted model but only found marginal effect and without proven interaction.

Lately, gut microbiota has received much attention in relation the development of immunological diseases, $C D$ included. Our living conditions have changed substantially with effects on diet, microbiota and infectious pattern, including antibiotic use. These changes influence our immune system, increasing the risk of allergic and autoimmune diseases. Against this background, the well-known hygiene hypothesis was first suggested by Strachan in 1989 [33]. Several studies have been made in developed countries that indicate an increase in CD $[3,34]$. Kondroshova et al. demonstrated that the hygiene hypothesis is perusable in CD development [7].

In line with the hygiene hypothesis, disturbed microbiota, or dysbiosis, have received more and more attention in CD research [35]. In the present study, we found an increased risk of $\mathrm{CD}$ in boys born with elective caesarean section. Similar results have been shown previously but without sex related differences [17]. Studies on Crohn's disease have also identified elective caesarean delivery as a risk factor [36, 37]. Children born by elective caesarean delivery are not exposed to the vaginal or faecal microbiota in contrast with children born through emergency caesarean delivery after initiated labour and ruptured membranes that get exposed to vaginal microbiota. We also found increased CD risk to be associated with maternal infections during pregnancy, in particular repeated urinary tract infections. During pregnancy, antibiotics are used to treat urinary tract infections, which could affect the gut microbiota that is later transferred to the neonate. Additionally, antibiotics have also been shown to increase $\mathrm{CD}$ risk directly [38]. Both elective caesarean section and repeated antibiotic treatment for urinary tract infections may lead to dysbiosis, resulting in disturbed maturation of the immune system in the child. Gut microbiota affect gut permeability, gut inflammatory activity (both directly and via the release of metabolites) and dysbiosis, all of which are suspected to play a role of increasing the risk of autoimmune disorders [39]. Moreover, we found a rather large reduction in $\mathrm{CD}$ risk to be associated with PROM. Due to the ruptured membranes, the baby is exposed to the maternal vaginal microbiota that is rich in lactobacillus species [40] for longer duration compared to normal delivery, theoretically this results in early colonization with lactobacilli. Lactobacilli have been shown to have a modulating effect on the immune response to gluten in cell culture and mouse models and could contribute to the protective effect of PROM seen in this study [41, 42]. However, this finding should be interpreted with caution since there were few cases and this hypothesis is speculative.

We found high income to be associated with reduced risk of $\mathrm{CD}$ during childhood while middle income was associated with increased risk. Previous studies both support and contradict our finding [16, 43-46]. Income could be associated with health during pregnancy, breastfeeding and early infant feeding. It is also possible that the effect of income is not associated with the child's foetal and early life, but with life style factors whose effect begin during later childhood, for example the amount of gluten ingested or other dietary factors. Possibly, health care seeking behaviour is dependent on income status. However, in Sweden health care is free up to the age of 18 and this should thus reduce this effect. Current evidence also suggests that individuals from low socio-economic positions are more likely to refrain from seeking health care, which would imply an underestimation of the effect [47]. Information on education could have offered better clarity but unfortunately was not available. We further compared children with mothers aged $\geq 35$ years, with high income and no urinary tract infection versus the other mothers and found synergistic effects on CD risk. We also report a positive but not statistically significant association between neonatal infections and $\mathrm{CD}$, although earlier studies have shown a significant positive association $[48,49]$.

We observed a protective effect due to maternal overweight and low birth weight in boys and low Apgar score in girls. High parity was also related to reduced CD risk, this did not support the hypothesis suggesting high parity to increase the infectious load of the index child. In a previous case-referent study, number of siblings did not affect $\mathrm{CD}$ risk [49]. Maternal overweight and low birth weight were associated with reduced CD risk. These findings were unexpected since both factors are known to have a negative impact on health. It is possible that these were chance findings or were due to residual confounding therefore interpretation should be done with caution.

Several variables were included and were tested for collinearity but found no such evidence. We conclude that the shown effects most likely represent the true magnitude in the adjusted models. In this study, the most significant findings had an OR close to 1 . This means that their impact on $\mathrm{CD}$ risk could be regarded as low to moderate. $\mathrm{CD}$ is a multifactorial disease with HLA DQ2 or HLA DQ8 and gluten as necessary causes. In addition to this, there are probably several environmental factors (some of which have been identified and others yet to be identified) that could contribute to CD risk. Thus it was unlikely that 
this study could identify variables with higher than the observed explanatory value for the risk of being diagnosed with $\mathrm{CD}$.

\section{Conclusions}

In this study, we found indications that elective caesarean section and maternal urinary tract infections are associated with increased risk of being diagnosed with $\mathrm{CD}$ during childhood; these two factors are related to possible gut dysbiosis. Additionally both findings were sex specific; differences in CD risk between boys and girls have been reported before and justify separate analysis in CD studies [44]. As a matter of fact, the considerable and well known higher $\mathrm{CD}$ risk in girls seen long before puberty is an interesting phenomenon that should be further studied [50]. We also found that maternal age with possible association to life style and diet (in particular breast feeding) is inversely related to $\mathrm{CD}$ risk. All factors could be linked to the development of the immune system. In future, preventive strategies could benefit by taking measures to prevent gut dysbiosis. Reduced prescription of antibiotics is one way that would also work to counteract the enormous problem with development of bacterial resistance to antibiotics. Promoting normal delivery would also be in line with goals in the field of maternal and child health. For some of our findings for example, increased CD risk was associated with being female, having maternal age 25-29 and being a second born, we could not establish a pathological mechanism. However it is worth remembering that one important role of epidemiological studies is to generate new hypotheses and thereby contribute to future search for disease mechanisms, possible treatment and prevention.

\section{Abbreviations}

$\mathrm{BMI}$, body mass index; $\mathrm{CD}$, celiac disease; $\mathrm{Cl}$, confidence intervals; OR, odds ratio; PIN, personal identification number; PROM, premature rupture of the membrane

\section{Acknowledgements}

The authors would like to thank Susanne Walther for her administrative support. The SIMSAM Lab data infrastructure used in this study was developed with the support of the Swedish Research Council and by strategic funds from Umeå University. The study was undertaken within the Centre for Global Health Research at Umeå University with support from the Swedish Council for Working Life and Social Research (FAS).

\section{Funding}

The study was funded by the Swedish Research Council through the program Swedish Initiative for Research on Microdata in the Social and Medical Sciences (SIMSAM) [839-2008-7491]. The study also received partial funding from the Swedish celiac disease association.

\section{Availability of data and materials}

Access to data is restricted to a secure data Lab, to comply with Swedish laws and regulations surrounding personal data and vetting the ethics of research. Details of how to access data are available on the Umeå SIMSAM Lab website: [www.simsam.org.umu.se].

\section{Author's contributions}

$\mathrm{Al}, \mathrm{OS}, \mathrm{CO}$ and $\mathrm{ML}$ were responsible for the conceptualization of the study and data collection. FN performed the statistical analyses and wrote the manuscript. ML supervised the analysis process and offered quality control of both data and the final study results. AM, UH, Al and OS provided clinical insights and interpretation of the study variables and the research findings. All authors contributed to the selection of the studied variables, choice of study design, interpretation of study findings, and revision of the manuscript, and have approved the submitted version of the manuscript.

\section{Competing interests}

The authors declare that they have no competing interests.

\section{Ethics approval and consent to participate}

The Regional Ethical Vetting Board in Umeå approved all research based on data from the Umeå SIMSAM Lab, including the present project.

\section{Author details}

${ }^{1}$ Department of Public Health and Clinical Medicine, Epidemiology and Global Health, Umeå University, SE-901 87 Umeå, Sweden. ${ }^{2}$ Department of Food and Nutrition, Umeå University, Umeå, Sweden. ${ }^{3}$ Department of Women's and Children's Health, Obstetrics and Gynaecology, Uppsala University, Uppsala, Sweden. ${ }^{4}$ Department of Clinical Sciences, Pediatrics, Umeå University, Umeå, Sweden.

Received: 27 February 2015 Accepted: 1 June 2016

Published online: 08 June 2016

\section{References}

1. Ludvigsson JF, Leffler DA, Bai JC, Biagi F, Fasano A, Green PH, Hadjivassiliou M, Kaukinen K, Kelly CP, Leonard JN, et al. The Oslo definitions for coeliac disease and related terms. Gut. 2013;62(1):43-52.

2. Namatovu F, Sandstrom O, Olsson C, Lindkvist M, Ivarsson A. Celiac disease risk varies between birth cohorts, generating hypotheses about causality: evidence from 36 years of population-based follow-up. BMC Gastroenterol. 2014;14:59.

3. Lohi S, Mustalahti K, Kaukinen K, Laurila K, Collin P, Rissanen H, Lohi O, Bravi E, Gasparin M, Reunanen A, et al. Increasing prevalence of coeliac disease over time. Aliment Pharmacol Ther. 2007;26:1217-25.

4. Ivarsson A, Persson LA, Nystrom L, Ascher H, Cavell B, Danielsson L, Dannaeus A, Lindberg T, Lindquist B, Stenhammar L, et al. Epidemic of coeliac disease in Swedish children. Acta Paediatr. 2000;89(2):165-71.

5. Parra-Medina R, Molano-Gonzalez N, Rojas-Villarraga A, Agmon-Levin N, Arango MT, Shoenfeld Y, Anaya JM. Prevalence of Celiac Disease in Latin America: A Systematic Review and Meta-Regression. Plos One. 2015;10(5):e0124040.

6. Kang JY, Kang AH, Green A, Gwee KA, Ho KY. Systematic review: worldwide variation in the frequency of coeliac disease and changes over time. Aliment Pharmacol Ther. 2013:38(3):226-45.

7. Kondrashova A, Mustalahti K, Kaukinen K, Viskari H, Volodicheva V, Haapala AM, llonen J, Knip M, Maki M, Hyoty H, et al. Lower economic status and inferior hygienic environment may protect against celiac disease. Ann Med. 2008:40(3):223-31.

8. Olsson C, Stenlund H, Hornell A, Hernell O, Ivarsson A. Regional variation in celiac disease risk within Sweden revealed by the nationwide prospective incidence register. Acta Paediatr. 2009;98(2):337-42.

9. Marques AH, O'Connor TG, Roth C, Susser E, Bjorke-Monsen AL. The influence of maternal prenatal and early childhood nutrition and maternal prenatal stress on offspring immune system development and neurodevelopmental disorders. Front Neurosci. 2013:7:120.

10. Odaka Y, Nakano M, Tanaka T, Kaburagi T, Yoshino H, Sato-Mito N, Sato K. The influence of a high-fat dietary environment in the fetal period on postnatal metabolic and immune function. Obesity (Silver Spring). 2010;18(9):1688-94.

11. Jakobsson HE, Abrahamsson TR, Jenmalm MC, Harris K, Quince C, Jernberg C, Bjorksten B, Engstrand L, Andersson AF. Decreased gut microbiota diversity, delayed Bacteroidetes colonisation and reduced Th1 responses in infants delivered by caesarean section. Gut. 2014;63(4):559-66.

12. Vangay P, Ward T, Gerber JS, Knights D. Antibiotics, pediatric dysbiosis, and disease. Cell Host Microbe. 2015;17(5):553-64.

13. Penders J, Thijs C, Vink C, Stelma FF, Snijders B, Kummeling I, van den Brandt PA, Stobberingh EE. Factors influencing the composition of the intestinal microbiota in early infancy. Pediatrics. 2006;118(2):511-21. 
14. Andreas NJ, Kampmann B, Mehring Le-Doare K. Human breast milk: A review on its composition and bioactivity. Early Hum Dev. 2015;91(11):629-35.

15. Decker E, Engelmann G, Findeisen A, Gerner P, Laass M, Ney D, Posovszky C, Hoy L, Hornef MW. Cesarean delivery is associated with celiac disease but not inflammatory bowel disease in children. Pediatrics. 2010;125(6):e1433-1440.

16. Roberts SE, Williams JG, Meddings D, Davidson R, Goldacre MJ. Perinatal risk factors and coeliac disease in children and young adults: a record linkage study. Aliment Pharmacol Ther. 2009;29(2):222-31.

17. Marild K, Stephansson O, Montgomery S, Murray JA, Ludvigsson JF. Pregnancy Outcome and Risk of Celiac Disease in Offspring: A Nationwide Case-control Study. Gastroenterology. 2012;142(1):39-45.e3.

18. Adlercreutz EH, Wingren CJ, Vincente RP, Merlo J, Agardh D. Perinatal risk factors increase the risk of being affected by both type 1 diabetes and coeliac disease. Acta Paediatr. 2015:104(2):178-84.

19. Ludvigsson JF, Otterblad-Olausson P, Pettersson BU, Ekbom A. The Swedish personal identity number: possibilities and pitfalls in healthcare and medical research. Eur J Epidemiol. 2009;24(11):659-67.

20. Walker-Smith JA, Guandalini S, Schmitz J, Shmerling DH, Visakorpi JK Revised criteria for diagnosis of coeliac disease. Report of Working Group of European Society of Paediatric Gastroenterology and Nutrition. Arch Dis Child. 1990;65(8):909-11.

21. Dickson BC, Streutker CJ, Chetty R. Coeliac disease: an update for pathologists. J Clin Pathol. 2006;59(10):1008-16.

22. Strachan DP, Taylor EM, Carpenter RG. Family structure, neonatal infection, and hay fever in adolescence. Arch Dis Child. 1996;74(5):422-6.

23. WHO statistical information system. Available from: Accessed 16 Nov2014 at [http://www.who.int/gho/publications/world_health_statistics/EN_WHS10_Full.pdf]

24. Husby S, Koletzko S, Korponay-Szabo IR, Mearin ML, Phillips A, Shamir R, Troncone R, Giersiepen K, Branski D, Catassi C, et al. European Society for Pediatric Gastroenterology, Hepatology, and Nutrition guidelines for the diagnosis of coeliac disease. J Pediatr Gastroenterol Nutr. 2012;54(1):136-60.

25. Al-Sahab B, Lanes A, Feldman M, Tamim H. Prevalence and predictors of 6-month exclusive breastfeeding among Canadian women: a national survey. BMC Pediatr. 2010;10:20

26. Jones JR, Kogan MD, Singh GK, Dee DL, Grummer-Strawn LM. Factors Associated With Exclusive Breastfeeding in the United States. Pediatrics. 2011;128(6):1117-25.

27. Oakley LL, Renfrew MJ, Kurinczuk JJ, Quigley MA: Factors associated with breastfeeding in England: an analysis by primary care trust. BMJ Open. 2013;3(6): e002765.

28. Akobeng AK, Thomas AG. Systematic review: tolerable amount of gluten for people with coeliac disease. Aliment Pharmacol Ther. 2008;27(11):1044-52.

29. Vriezinga SL, Auricchio R, Bravi E, Castillejo G, Chmielewska A, Crespo Escobar P, Kolacek S, Koletzko S, Korponay-Szabo IR, Mummert E, et al. Randomized feeding intervention in infants at high risk for celiac disease. $\mathrm{N}$ Engl J Med. 2014;371(14):1304-15

30. Lionetti E, Castellaneta S, Francavilla R, Pulvirenti A, Tonutti E, Amarri S, Barbato M, Barbera C, Barera G, Bellantoni A, et al. Introduction of gluten, HLA status, and the risk of celiac disease in children. N Engl J Med. 2014;371(14):1295-303.

31. Aronsson CA, Lee HS, Liu E, Uusitalo U, Hummel S, Yang J, Hummel M, Rewers M, She JX, Simell O, et al. Age at gluten introduction and risk of celiac disease. Pediatrics. 2015;135(2):239-45.

32. Stordal $K$, White RA, Eggesbo M. Early feeding and risk of celiac disease in a prospective birth cohort. Pediatrics. 2013;132(5):e1202-1209.

33. Strachan DP. Hay fever, hygiene, and household size. BMJ. 1989;299(6710): 1259-60.

34. White LE, Merrick VM, Bannerman E, Russell RK, Basude D, Henderson P, Wilson DC, Gillett PM. The Rising Incidence of Celiac Disease in Scotland. Pediatrics. 2013;132(4):e924-931.

35. Pozo-Rubio T, Olivares M, Nova E, De Palma G, Mujico JR, Ferrer MD, Marcos A, Sanz Y. Immune development and intestinal microbiota in celiac disease. Clin Dev Immunol. 2012;2012:654143.

36. Malmborg P, Bahmanyar S, Grahnquist L, Hildebrand H, Montgomery S. Cesarean section and the risk of pediatric Crohn's disease. Inflamm Bowel Dis. 2012;18(4):703-8.

37. Ponsonby AL, Catto-Smith AG, Pezic A, Dupuis S, Halliday J, Cameron D, Morley R, Carlin J, Dwyer T. Association between early-life factors and risk of child-onset Crohn's disease among Victorian children born 1983-1998: a birth cohort study. Inflamm Bowel Dis. 2009;15(6):858-66.
38. Marild K, Ye W, Lebwohl B, Green PH, Blaser MJ, Card T, Ludvigsson JF. Antibiotic exposure and the development of coeliac disease: a nationwide case-control study. BMC Gastroenterol. 2013;13:109.

39. McLean MH, Dieguez Jr D, Miller LM, Young HA. Does the microbiota play a role in the pathogenesis of autoimmune diseases? Gut. 2015;64(2):332-41.

40. Romero R, Hassan SS, Gajer P, Tarca AL, Fadrosh DW, Nikita L, Galuppi M, Lamont RF, Chaemsaithong P, Miranda J, et al. The composition and stability of the vaginal microbiota of normal pregnant women is different from that of non-pregnant women. Microbiome. 2014;2(1):4.

41. Laparra JM, Sanz Y. Bifidobacteria inhibit the inflammatory response induced by gliadins in intestinal epithelial cells via modifications of toxic peptide generation during digestion. J Cell Biochem. 2010;109(4):801-7.

42. Cinova J, De Palma G, Stepankova R, Kofronova O, Kverka M, Sanz Y, Tuckova L. Role of intestinal bacteria in gliadin-induced changes in intestinal mucosa: study in germ-free rats. PLoS One. 2011;6(1):e16169.

43. Olen O, Bihagen E, Rasmussen F, Ludvigsson JF. Socioeconomic position and education in patients with coeliac disease. Dig Liver Dis. 2012;44(6):471-6.

44. Wingren CJ, Bjorck S, Lynch KF, Ohlsson H, Agardh D, Merlo J. Coeliac disease in children: a social epidemiological study in Sweden. Acta Paediatr. 2012;101(2):185-91.

45. Whyte LA, Kotecha S, Watkins WJ, Jenkins HR. Coeliac disease is more common in children with high socio-economic status. Acta Paediatr. 2014;103(3):289-94.

46. Stenhammar L, Hogberg L, Ivarsson A, Laurin P, Myleus A, Falth-Magnusson K. Coeliac disease and socio-economic status. Acta Paediatr. 2014;103(8):e328

47. Westin M, Ahs A, Brand Persson K, Westerling R. A large proportion of Swedish citizens refrain from seeking medical care-lack of confidence in the medical services a plausible explanation? Health Policy. 2004;68(3):333-44.

48. Welander A, Tjernberg AR, Montgomery SM, Ludvigsson J, Ludvigsson JF. Infectious disease and risk of later celiac disease in childhood. Pediatrics. 2010;125(3):e530-536.

49. Myleus A, Hernell O, Gothefors L, Hammarstrom ML, Persson LA, Stenlund $H$, Ivarsson A. Early infections are associated with increased risk for celiac disease: an incident case-referent study. BMC Pediatr. 2012;12:194.

50. Ivarsson A, Persson LA, Nystrom L, Hernell O. The Swedish coeliac disease epidemic with a prevailing twofold higher risk in girls compared to boys may reflect gender specific risk factors. Eur J Epidemiol. 2003;18(7):677-84.

\section{Submit your next manuscript to BioMed Central and we will help you at every step:}

- We accept pre-submission inquiries

- Our selector tool helps you to find the most relevant journal

- We provide round the clock customer support

- Convenient online submission

- Thorough peer review

- Inclusion in PubMed and all major indexing services

- Maximum visibility for your research

Submit your manuscript at www.biomedcentral.com/submit 